\title{
Sistem Informasi Pemesanan Tiket Travel Berbasis Web (Studi Kasus: Lantra Wisata Travel PO. Sejahtera)
}

\author{
Yurika Nopianti ${ }^{1}$, Ruliansyah ${ }^{2}$, Evi Fadilah $^{3}$ \\ yurikanopianti@yahoo.com ${ }^{1}$, ruli@radenfatah.ac.id ${ }^{2}$, evifadilah_uin@ $@$ radenfatah.ac.id ${ }^{3}$ \\ ${ }^{1}$ Prodi Sistem Informasi, Fakultas Sains dan Teknologi, UIN Raden Fatah Palembang \\ ${ }^{2}$ Prodi Sistem Informasi, Fakultas Sains dan Teknologi, UIN Raden Fatah Palembang \\ ${ }^{3}$ Prodi Sistem Informasi, Fakultas Sains dan Teknologi, UIN Raden Fatah Palembang
}

Diterima: 22 Agustus 2017 | Direvisi: 21 Agustus 2017 | Disetujui: 27 November 2017

(c) 2017 Program Studi Sistem Informasi Fakultas Sains dan Teknologi,

Universitas Islam Negeri Raden Fatah Palembang, Indonesia

\begin{abstract}
Abstrak: Kebutuhan sistem transportasi yang tinggi, dijadikan oleh banyak orang sebagai salah satu peluang usaha yang menguntungkan. Untuk itu mereka membuat suatu usaha untuk mempermudah masyarakat dalam melakukan mobilitas, dengan cepat dan mudah. Untuk kegiatan pemesanan tiket lantra wisata travel saat ini dilakukan secara konvensional, yaitu customer harus datang ke outlet perwakilan secara langsung sehingga memakan waktu yang cukup lama. Petugas operator travel sering mengalami kesulitan dalam melakukan pencarian data customer, mengupdate data customer, kesalahan dalam hal pemberian nomor kursi atau pencatatan jam keberangkatan yang diinginkan oleh calon customer. Hal ini sering menyebabkan ketidak akuratan data akibat kurang cermat sehingga menghambat kinerja karyawan dalam melaksanakan tugasnya. Penelitian ini membangun sistem informasi yang dapat membantu otomatisasi proses pemesanan tiket. Sistem informasi yang dibuat berbasis web dengan menggunakan metode waterfall. Sistem yang dibangun dapat membantu pihak travel dalam mengelola data pemesanan tiket sehingga mempermudah customer dalam proses pemesanan tiket dan operator dalam pengelolaan data travel.
\end{abstract}

Kata Kunci: Sistem Informasi, Pemesanan Tiket, Waterfall

\begin{abstract}
The need for a transportation system, made by many people as one of the profitable business opportunities. And then they make on effort to facilitate the community in doing mobility, quickly and easily. At this time booking tickets on Lantra Wisata Travel is still manual. The customer must come to the representative outlet directly so it take a long time. Officers travel operators often have difficultly in searching customer data, updating customer data, errors in terms of giving the number of seats or recording the departure hours desired by prospective customers. This often causes inaccurate date due to lack of accuracy that hampers the performance of employees in performing their duties. This research bulls an information system that can help automate ticket booking process. Information system made web- based using waterfall method. The built system can help the travel in managing ticket booking data so as to facilitate the customer in the process of booking tickets and operators in the management of travel data.
\end{abstract}

Keywords: Information System, Booking Ticket, Waterfall

\section{PENDAHULUAN}

Perkembangan sistem transportasi hadir untuk mendukung kinerja orang-orang di Indonesia untuk meningkatkan kualitas hidup mereka. Tidak bisa dihindari lagi, bahwa pada masa ini, sistem transportasi merupakan salah satu kebutuhan yang sangat penting dan bahkan menjadi salah satu faktor pengendali kehidupan manusia. Di masa ini, jumlah penduduk Indonesia meningkat sangat tinggi, jumlah penduduk yang tinggi, menjadi faktor penyebab meningkatnya mobilitas masyarakat dalam kehidupan sehari-hari. Tingginya mobilitas 
masyarakat terutama di Indonesia, membuat sistem transportasi diperlukan untuk mendukung penuh dalam mobilitas tersebut. Kebutuhan sistem transportasi yang tinggi, dijadikan oleh banyak orang di masa kini, sebagai salah satu peluang usaha yang menguntungkan. Untuk itu mereka membuat suatu usaha untuk mempermudah masyarakat dalam melakukan mobilitas, dengan cepat, dan mudah.

Usaha-usaha itu sangat berkembang pesat di masa ini, yaitu usaha di bidang travel. Dalam dunia industri travel, banyak sekali data yang dikelola dan pengelolaan tersebut dilakukan hampir setiap hari. Pengelolaan data yang sangat banyak akan menjadi sangat rumit. Data-data dalam industri travel sangatlah banyak dan memiliki sifat yang selalu berubah-ubah, dan perubahan data tersebut tidak menentu setiap waktunya. Pengelolaan yang dilakukan secara manual dapat memiliki kemungkinan pengelolaan data menjadi tidak akurat dan menimbulkan beberapa kesalahan.

Lantra Wisata Travel merupakan salah satu perusahaan jasa transportasi yang beroperasi di Sumatera Selatan. Jasa transportasi Lantra Wisata Travel lebih banyak digunakan oleh perantau saat kembali ke Lahat, Muara Enim, Prabumulih dan Palembang melalui Lahat dan sebaliknya. Letak lokasi loket Lahat Wisata Travel yaitu jl. Letnan Marzuki Talang Jawa No.015/092 (Lahat) dan jl. Kol Atmo No. 1260 (Palembang). Dalam melakukan kegiatan pelayanannya saat ini, Lantra Wisata Travel masih belum menggunakan sistem yang terkomputerisasi. Proses pemesanan tiket dengan konvensional, menyebabkan customer kesulitan karena harus datang ke outlet perwakilan secara langsung atau dengan menelpon pihak operator travel, belum lagi jika banyak calon customer yang akan memesan tiket mengakibatkan antrian yang panjang atau kehabisan tiket. Selain itu customer sering dikejutkan dengan harga tiket yang melonjak naik dikarenakan tidak ada daftar harga pasti. Selain customer, petugas operator travel juga sering mengalami kesulitan dalam melakukan pencarian data customer atau calon customer travel, misalnya tanggal pemesanan, tujuan keberangkatan, dan kesulitan dalam hal mengupdate data pelanggan jika ingin mengubah status pembayaran.

Terjadinya kesalahan data dalam hal pemesanan tiket, misalnya kesalahan dalam hal pemberian nomor kursi yang telah dipesan atau kesalahan pencatatan jam keberangkatan yang diinginkan oleh calon customer. Kesulitan dalam memonitoring perkembangan mengenai jadwal keberangkatan travel dengan jumlah ketersediaan kursi yang masih kosong hal ini sering menyebabkan ketidakakuratan data akibat kurang cermat sehingga menghambat kinerja operator dalam melaksanakan tugasnya. Pencatatan transaksi pemesanan dilakukan secara konvensional, yaitu dicatat menggunakan kuitansi pemesanan tiket dan dicatat kembali ke dalam buku besar untuk di rekapitulasi sehingga kurang efektif dan membutuhkan waktu, belum lagi permasalahan hilangnya kuitansi tiket pencatatan pemesanan.

\section{METODOLOGI PENELITIAN}

Tujuan dari penelitian ini adalah Membangun sistem informasi pemesanan tiket berbasis web pada Lantra Wisata Travel (Perusahaan Otobus) PO. Sejahtera.

\subsection{Tinjauan Pustaka}

\subsubsection{Sistem Informasi}

Sistem informasi secara teknis didefinisikan sebagai satuan komponen yang saling berhubungan, yang mengumpulkan (atau mendapatkan kembali), memproses, menyimpan, dan mendistribusikan informasi untuk mendukung pengambilan keputusan dan kendali dalam suatu organisasi. Sistem informasi dapar juga membantu para manager dan karyawan untuk meneliti permasalahan, memvisualisasikan pokok-pokok yang kompleks, dan menciptakan produk-produk baru (Gaol, 2008).

\subsubsection{PHP}

PHP merupakan secara umum dikenal sebagai bahasa pmrograman script- script yang membuat dokumen HTML secara on the fly yang dieksekusi di sever web, dokumen HTML 
yang dihasilkan dari suatu aplikasi bukan dokumen HTML yang dibuat dengan menggunakan editor teks atau editor HTML. Dikenal juga sebagai bahasa pemrograman server side (Sidik, 2006).

PHP merupakan bahasa pemrograman pelengkap HTML yang memungkinkan dibuatnya aplikasi web dinamis untuk pengolahan data, pemrosesan data dari user via form, membuat buku tamu, toko online, dan lain sebagainya. Dengan mudah PHP dapat melakukan koneksi ke database karena PHP memang dilengkapi fitur yang memungkinkan koneksi ke PHP dilakukan dengan mudah, tanpa harus melakukan pemrograman yang memusingkan (Tim EMS, 2014).

\subsubsection{Data Flow Diagram (DFD)}

(Sukamto, R. A., \& Shalahuddin, M., 2013), Data Flow Diagram (DFD) adalah representasi grafik yang menggambarkan aliran informasi dan transformasi informasi yang diaplikasikan sebagai data yang mengalir dari masukan (input) dan keluaran (output).

\subsection{Metode Pengumpulan Data}

\subsubsection{Observasi}

Observasi langsung terhadap alur proses yang sedang berjalan pada Lantra Wisata Travel untuk memperoleh informasi dan permasalahan yang nantinya akan diperoleh datadata penting dari tempat penelitian.

\subsubsection{Wawancara}

Wawancara untuk mencari dan mengumpulkan data dengan cara langsung berbicara dengan Operator Travel, data yang di dapatkan berupa informasi mengenai sistem yang berjalan saat ini.

\subsubsection{Dokumentasi}

Dokumentasi data yang dilakukan dengan mengamati dokumen yang dimiliki dan disediakan oleh Lantra Wisata Travel untuk diolah peneliti. Dokumen yang diperlukan antara lain data pemesanan tiket travel.

\subsubsection{Kepustakaan}

Kepustakaan yaitu Pengumpulan data yang dilakukan secara langsung dari sumbersumber lain seperti buku, jurnal dan hasil penelitian yang berkaitan dengan permasalahan

\subsection{Metode Pengembangan Sistem}

Menurut (Pressman, 2012), Model air terjun (waterfall) kadang dinamakan siklus hidup klasik (classic life cycle), dimana hal ini menyiratkan pendekatan yang sistematis dan berurutan (sekuensial). Pada pengembangan perangkat lunak, yang dimulai dengan spesifikasi kebutuhan pengguna dan berlanjut melalui tahapan-tahapan perencanaan, pemodelan, kontruksi serta penyerahan sistem/perangkat lunak kepara pelanggan/pengguna, yang diakhiri dengan dukungan berkelanjutan pada perangkat lunak lengkap yang dihasilkan yaitu terdapat pada Gambar berikut:

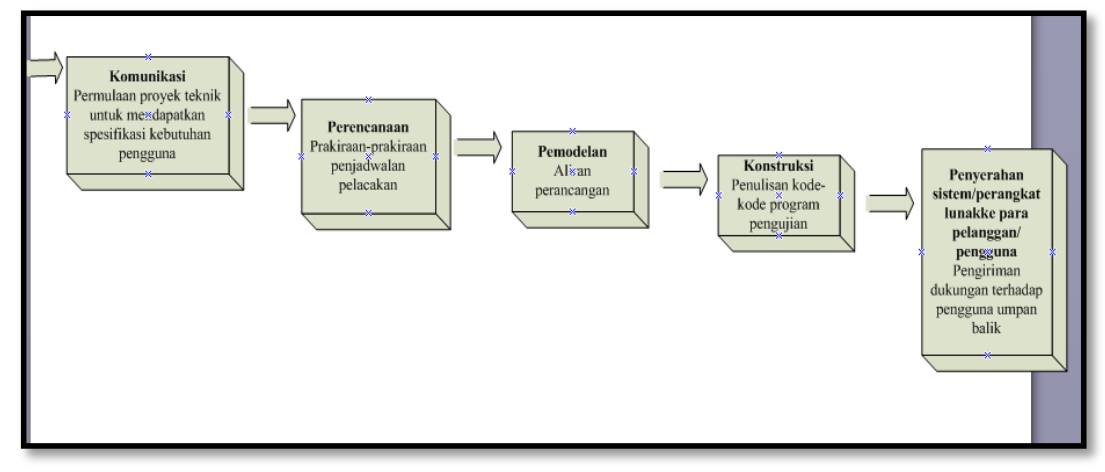

Gambar 1. Model Waterfall 


\section{HASIL DAN PEMBAHASAN}

\subsection{Pemodelan}

Tahapan pemodelan atau desain sistem yang dibangun dibagi menjadi desain proses sistem yang dibangun direpresentasikan menggunakan aliran data sistem Data Flow Diagram (DFD), representasi relasi menggunakan Entity Relationship Diagram (ERD).

\subsubsection{Data Flow Diagram (DFD)}

DFD merepresentasikan aliran data sistem yang dibangun, setiap data yang yang menjadi input dan akan melalui proses sistem dan menjadi output. Representasi aliran data dari sistem yang dibangun menggunakan Data Flow Diagram (DFD) yang terdiri dari: Diagram konteks (top level), diagram rinci (level 0), dan diagram rinci (level 1).

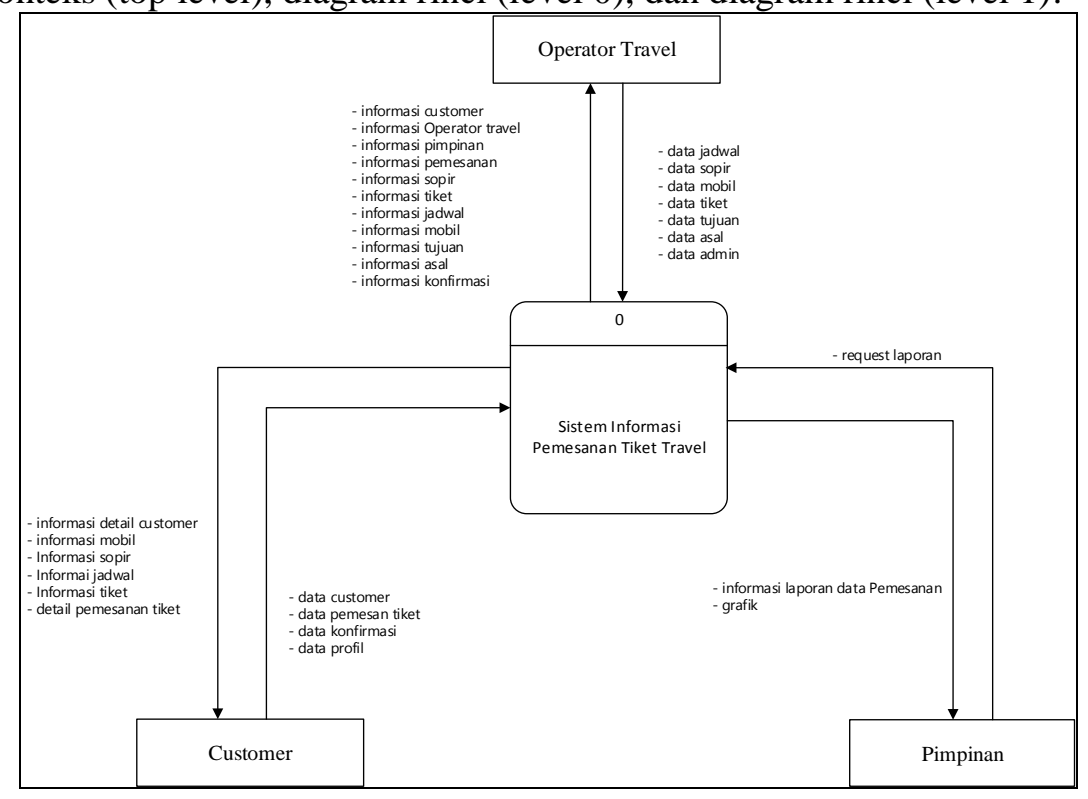

Gambar 2. Diagram konteks

Diagram konteks menampilkan arus data input dan output dari masing-masing entitas dan melalui SI-Pemesanan Tiket Travel. Entitas yang terdapat pada diagram konteks berjumlah 3 entitas, yaitu Operator travel (admin), Customer, Pimpinan. Dapat dilihat pada Gambar 3.

\subsubsection{Entity Relationship Diagram (ERD)}

Diagram ERD menampilkan relasi antar entitas sebagai dasar dari implementasi database yang nantinya akan terdapat pada sistem yang dibangun. Dapat dilihat pada . 


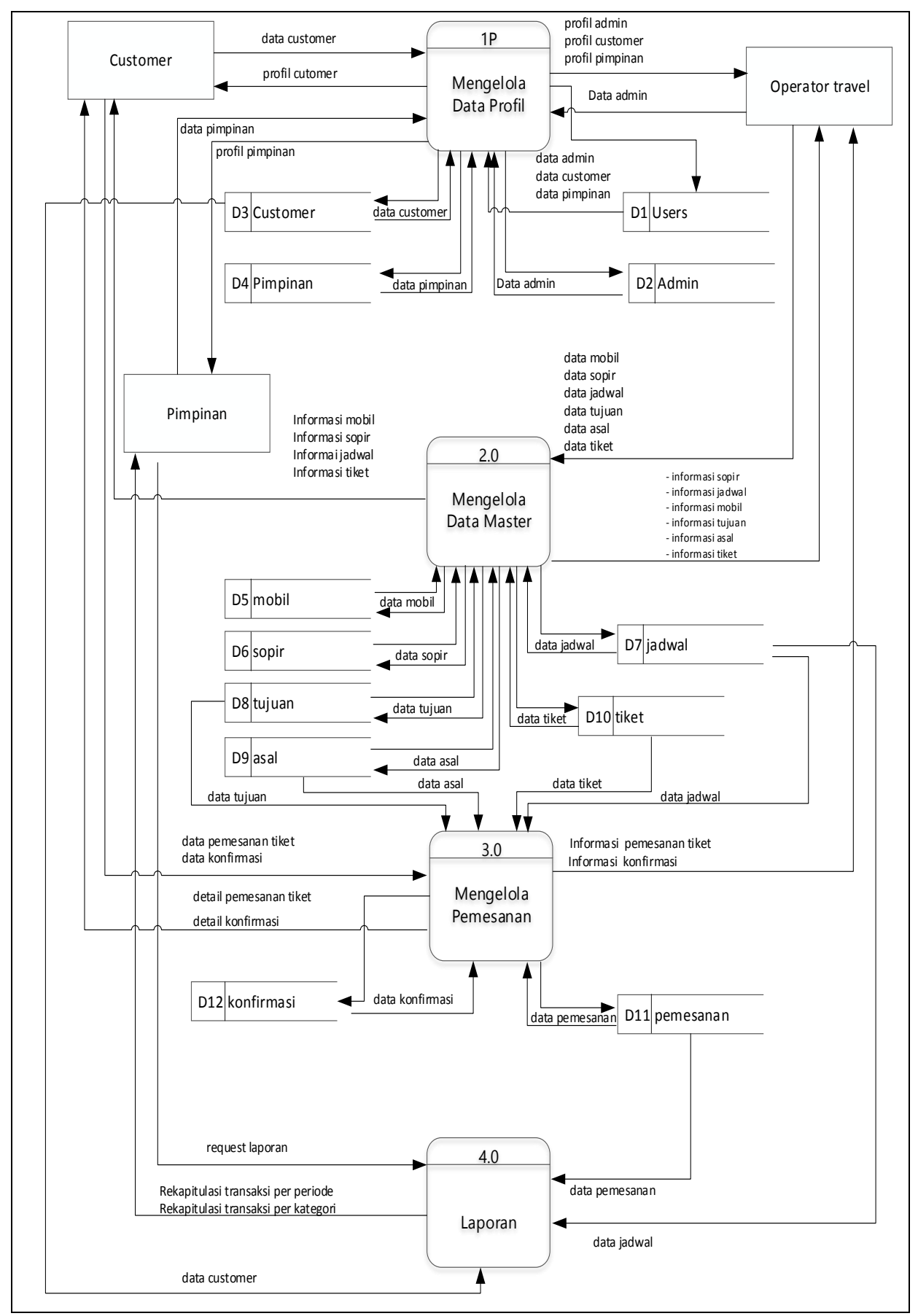

Gambar 3. Diagram Rinci (Level 0) 


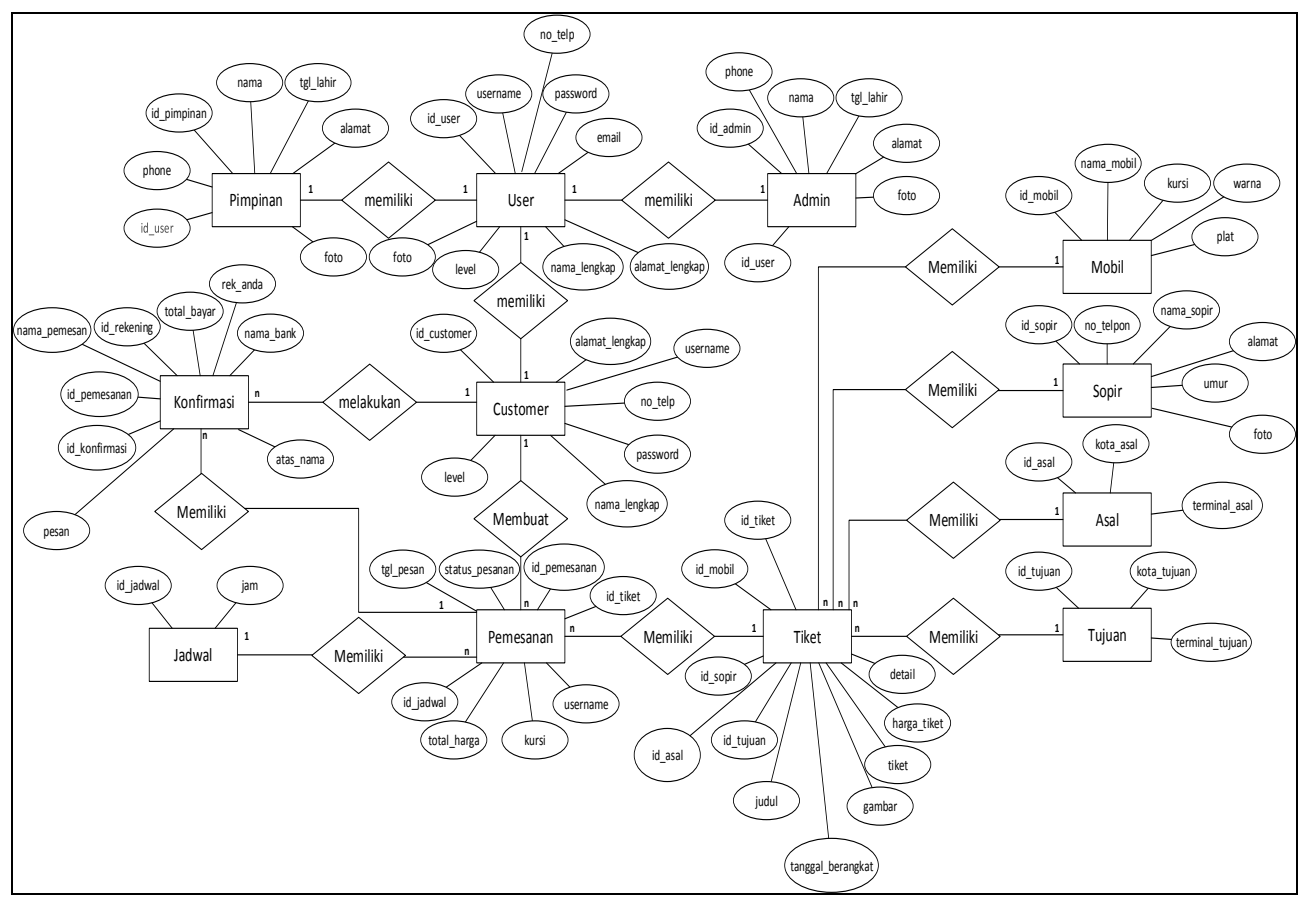

Gambar 4. Diagram Relasi Antar Entitas (ERD)

\subsection{Implementasi}

\subsubsection{Halaman Beranda}

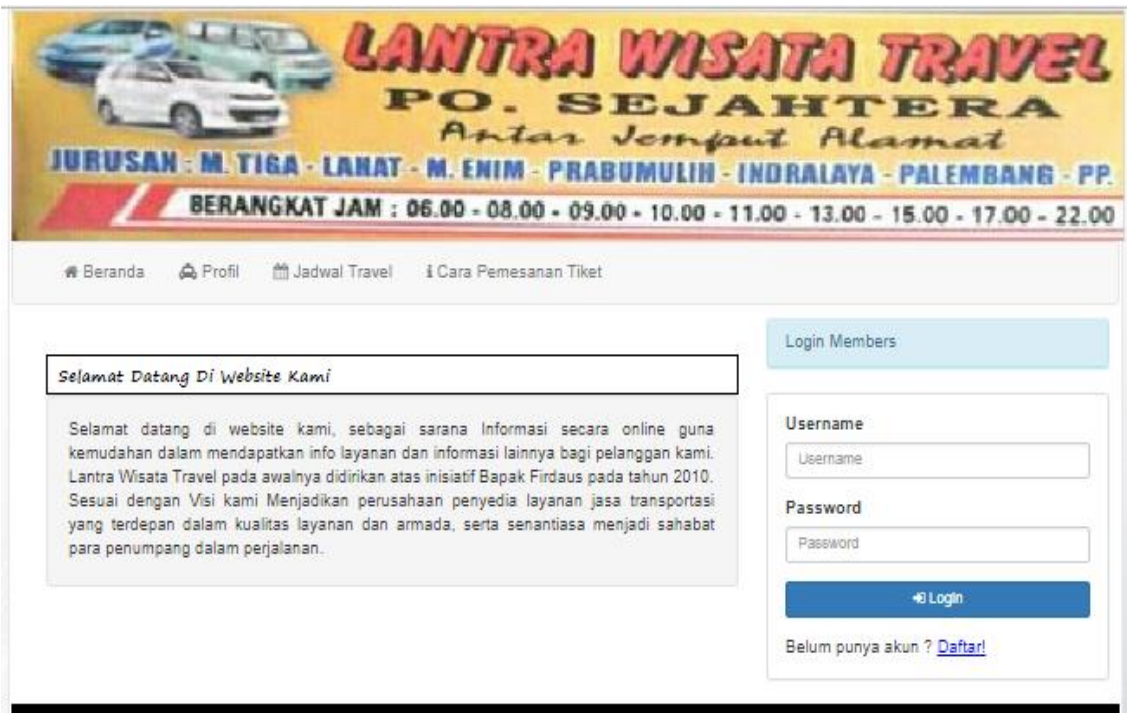

Gambar 5. Halaman Beranda

Halaman utama pada SI-Pemesanan Tiket Travel menampilkan pengumuman yang dipublikasi dan konten login dengan header disertai menu navigasi yang memuat hyperlink menuju alamat URL lain, dan halaman. Bagian footer pada antarmuka front-end menampilkan hyperlink lpm. 


\subsubsection{Halaman Login}

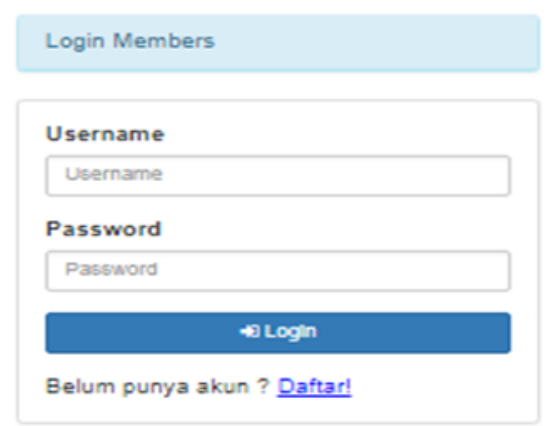

Gambar 6. Halaman Login

\subsubsection{Halaman Pendaftaran Customer}

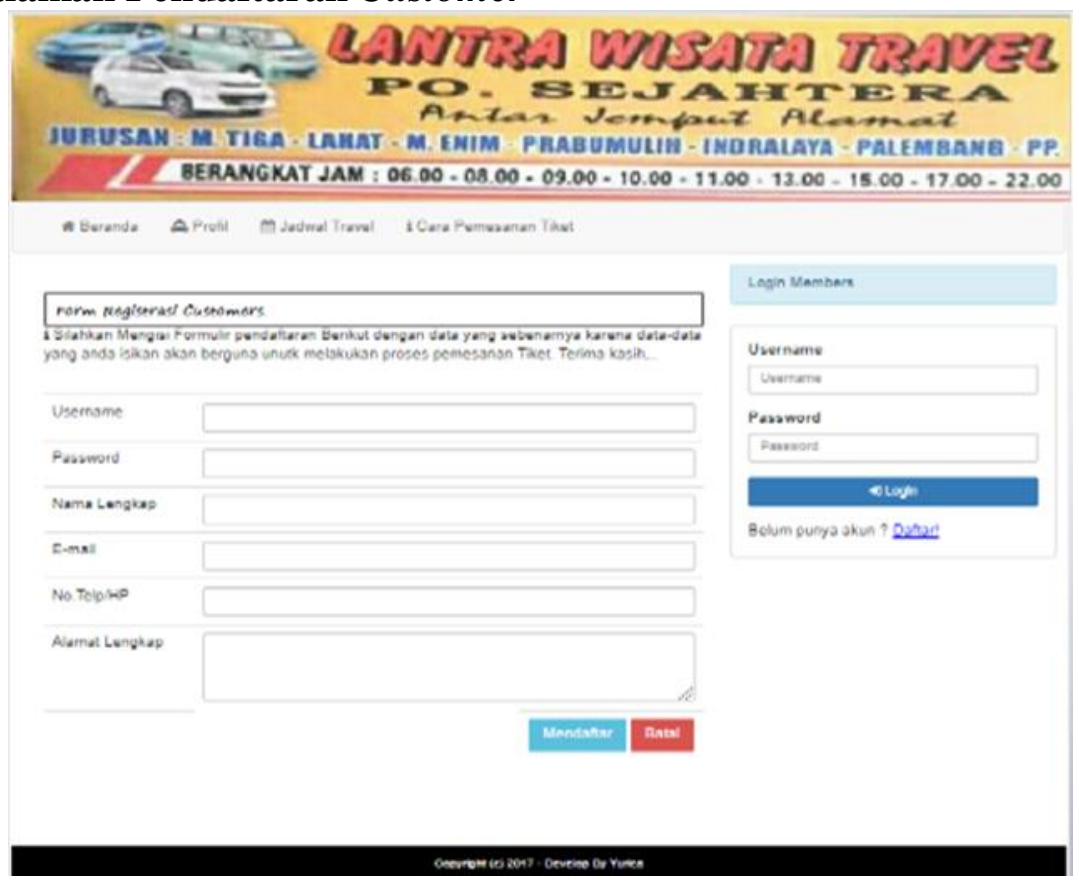

Gambar 7. Halaman Pendaftaran Customer

\subsubsection{Laporan Pemesanan Tiket}

Halaman laporan pemesanan tiket menampilkan semua daftar pemesanan tiket oleh members. Tabel utama menampilkan nama tiket yang tersedia dengan aksi 'detail' untuk melihat secara detail data pemesanan tiket dan 'cetak' untuk mencetak pemesanan menghapus data, penambahan tiket dengan mengklik button 'tambah data', serta mengklik button 'cari' untuk mencari berdasarkan nama tiket dan jadwal. button 'print' untuk mencetak berdasarkan nama tiket, serta button 'print all' untuk mencetak keseluruhan pemesanan tiket. 


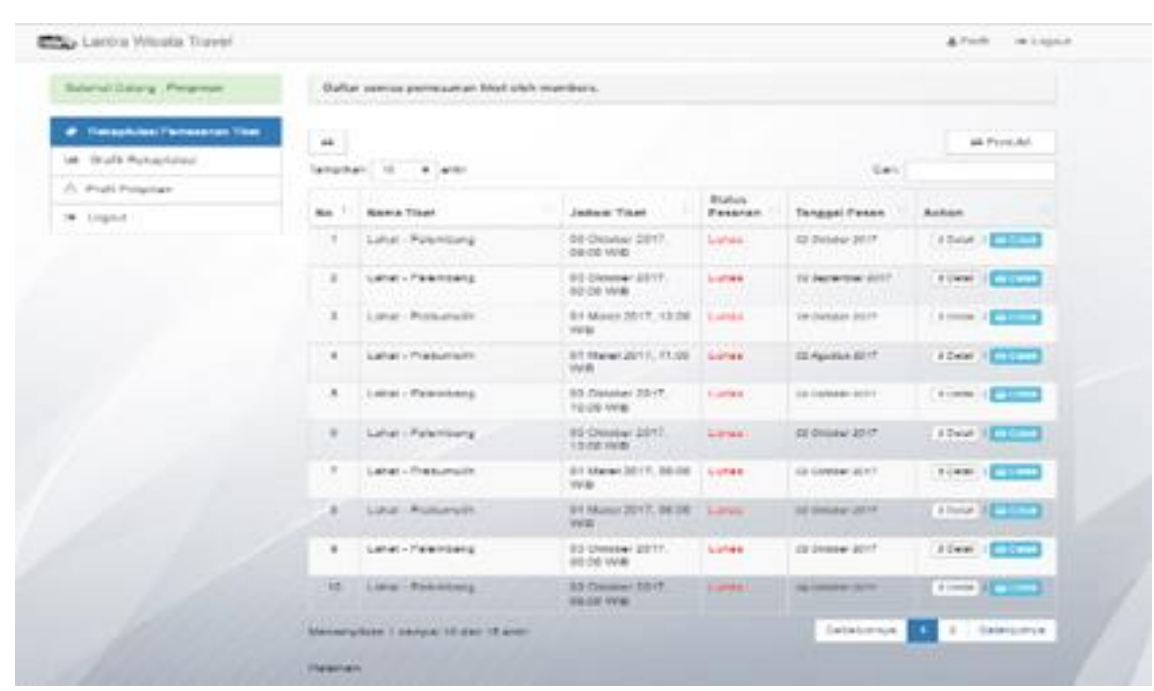

Gambar 8. Halaman Laporan Pemesanan Tiket

\section{KESIMPULAN}

Dari hasil penelitian yang dilakukan, maka dapat diambil kesimpulan yaitu membangun sistem informasi pemesanan tiket travel dilakukan dengan menggunakan metode pengembangan sistem Waterfall, dengan pemodelan DFD (Data flow Diagram) serta menggunakan bahasa pemrograman PHP dengan pengelolaan data MySQL. Sistem Informasi Pemesanan Tiket Travel Pada Lantra Wisata Travel (Perusahaan Otobus) PO. Sejahtera dibangun untuk membantu proses pemesanan tiket sehingga mempermudah customer untuk melakukan pemesanan tiket, konfirmasi pembayaran, serta melihat dan memilih tujuan, jadwal keberangkatan, dan letak duduk yang diinginkan. Sistem yang dibuat juga dapat membantu bagian operator dalam melakukan pencarian data customer, melihat detail pemesanan, dan mengelola data jadwal keberangkatan travel. Penelitian ini menghasilkan sistem yang dapat menyimpan dan mengelola data-data travel.akreditasi secara online dan juga membuat evaluasi borang lebih efektif dan efisien.

\section{DAFTAR RUJUKAN}

Gaol, C. J. (2008). Sistem Informasi Manajemen: Pemahaman dan Aplikasi. Bandung: Informatika.

Pressman, R. (2012). Rekayasa Perangkat Lunak (Pendekatan Praktisi) Edisi 7. Yogyakarta: Andi.

Sidik, B. (2006). Pemrograman Web Dengan PHP. Bandung: Informatika.

Sukamto, R. A., \& Shalahuddin, M. (2013). Rekayasa Perangkat Lunak Terstruktur dan Berorientasi Objek. Bandung: Informatika.

Tim EMS. (2014). Teori dan Praktik PHP - MySQL untuk Pemula. Jakarta: PT. Elex Media

Komputindo. 